\title{
Early-onset Cardiotoxicity assessment related to anthracycline in children with leukemia. A Prospective Study
}

\section{Evaluación de la cardiotoxicidad temprana asociada al tratamiento con antraciclinas en niños con Leucemia. Estudio prospectivo.}

\author{
Adriana Linares Ballesteros ${ }^{1,2}$ Roy Sanguino Lobo $^{3}$ (D) Juan Camilo Villada Valencia ${ }^{1}$ \\ Oscar Arévalo Leal ${ }^{(\mathbb{D})}$ Diana Constanza Plazas Hernández ${ }^{1,2}$ Nelson Aponte Barrios ${ }^{2}$ \\ Iván Perdomo Ramírez ${ }^{4}$ D \\ rsanguinol@homifundacion.org.co
}

OPEN ACCESS

Citation: Linares BA, Sanguino LR, Villada VJC, Areválo LO, Plazas HDC, Aponte BN, Perdomo RI. Early-onset Cardiotoxicity assessment related to anthracycline in children with leukemia. A Prospective Study. Colomb Med (Cali). 2021;

52(1):e2034542 http://doi. org/10.25100/cm.v52i 1.4542

Received : 08 Sep 2020

Revised: 22 Jan 2021

Accepted : 10 Feb 2021

Published: 15 Feb 2021

Keywords:

Child; leukemia; anthracyclines; antineoplastic agents; ventricular dysfunction; echocardiography; drug therapy.

Palabras clave:

Niño; quimioterapia; toxicidad; biomarcadores; leucemia; ecocardiografía; antraciclinas; disfunción ventricular; antineoplásicos

Copyright: (c) 2021 Universidad del Valle.

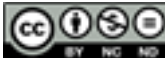

\begin{abstract}
1 Universidad Nacional de Colombia, Facultad de Medicina, Departamento de Pediatría, Bogotá, Colombia 2 Fundación Hospital Pediátrico de la Misericordia-HOMI, Oncohematología pediátrica, Bogotá Colombia, 3 Fundación Hospital Pediátrico de la Misericordia-HOMI, Cardiología pediátrica, Bogotá Colombia, 4 Fundación Hospital Pediátrico de la MisericordiaHOMI, Unidad Cuidado Intensivo pediátrico, Bogotá Colombia
\end{abstract}

\section{Abstract}

\section{Background:}

Acute leukemias are the most frequent malignancies in children. Advances in treatment have improved the overall survival to $80 \%$. Almost $10 \%$ of children with cancer develop clinical cardiac toxicity. Total anthracycline cumulative dose is a risk factor for early-onset cardiotoxicity.

\section{Objective:}

To describe the incidence of early-onset cardiotoxicity in children with acute leukemia treated with chemotherapy.

\section{Methods:}

A prospective descriptive study of patients $>1$ y and $<18$ years diagnosed with acute leukemia. Assessed with electrocardiogram, echocardiography, and blood biomarkers at diagnosis and during the follow-up.

Results:

94 patients with acute lymphoblastic leukemia and 18 with acute myeloid leukemia were included. 20 patients $(17.9 \%)$ developed early-onset cardiotoxicity. Statistically significant data was seen after anthracycline dose $>150 \mathrm{mg} / \mathrm{m} 2$, between the first echocardiographic evaluation and posterior analyses in the left ventricular fraction ejection with Teicholz p 0.05, Simpson p 0.018 and GLS p 0.004. In this study, there was no relation between blood biomarkers and cardiotoxicity.

\section{Conclusions:}

Cancer therapeutic-related cardiac dysfunction is related to anthracycline cumulative dose. In this study, echocardiographic follow-up was useful to predict risk factors for early cardiac dysfunction. 
Conflicts of interest:

none declared.

\section{Funding:}

This study was supported by Universidad Nacional de ColombiaBogotá Research Division, Hermes project \# 37523, and the Research Office of HOMI Fundación Hospital de La Misericordia, Bogotá-Colombia.

Corresponding author: Roy Sanguino Lobo. Fundación Hospital Pediátrico de la Misericordia-HOMI, Cardiología pediátrica, Bogotá Colombia. e-mail: rsanguinol@ homifundacion.org.co

\section{Resumen}

\section{Antecedentes:}

Las leucemias son la principal causa de cáncer infantil. Los avances en el tratamiento han llevado a los pacientes a una supervivencia global hasta del $80 \%$. Cerca del $10 \%$ de los niños con cáncer tienen toxicidad cardiovascular sintomática, la dosis acumulada de antraciclinas es un factor de riesgo para afección cardíaca.

\section{Objetivo:}

Describir la frecuencia de afectación cardíaca temprana en niños con leucemias agudas que recibieron tratamiento antineoplásico.

\section{Métodos:}

Estudio prospectivo observacional, de pacientes $<18$ años con diagnóstico confirmado de leucemia aguda. Fueron evaluados con electrocardiograma, ecocardiograma bidimensional y biomarcadores séricos en diferentes momentos durante el tratamiento.

\section{Resultados:}

Se evaluaron 94 pacientes con leucemia linfoide aguda y 18 con leucemia mieloide aguda. 20 pacientes $(17.9 \%)$ tuvieron disfunción cardiaca de inicio temprano. Se observaron diferencias estadísticamente significativas, después de recibir $150 \mathrm{mg} / \mathrm{m} 2$ de antraciclinas, entre la evaluación del ecocardiograma basal y evaluaciones posteriores de la fracción de eyección ventricular izquierda por Teicholz $p 0.05$, fracción de eyección ventricular izquierda por Simpson $p 0.018$ y la deformación longitudinal global $p$ 0.004. No se encontraron alteraciones en los niveles séricos de las troponinas y péptido natriurético cerebral.

\section{Conclusiones:}

La disfunción cardíaca relacionada con quimioterapia estuvo directamente relacionada con las dosis acumuladas de antraciclinas. En este estudio el uso del ecocardiograma como método de seguimiento permitió identificar factores predictores de riesgo para disfunción cardiaca temprana.

\section{Remark}

\section{1) Why was this study conducted?}

There are few prospective studies on the frequency of early cardiac toxicity in children receiving chemotherapy and possible predictors of this toxicity in children receiving acute leukemia treat ment.

\section{2) What were the most relevant results of the study?}

Up to $75 \%$ of children have some abnormal cardiovascular finding during treatment. The usefulness of advanced echocardiography tools in predicting the risk of cardiac compromise with significant OR. We established GLS and GLS delta's role as possible early markers of cardiac toxicity in children who received treatment for acute leukemias. Biomarkers were not predictors of cardiotoxicity in this study. The relationship between cardiac disease and cumulative anthracycline doses was demonstrated.

\section{3) What do these results contribute?}

Motivating the identification of cardiovascular compromise as an adverse effect of chemotherapy in children during cancer treatment and promoting measures to mitigate it, such as the use of cardiac protection strategies. It is necessary to conduct long-term follow-up of leukemia survivors to identify late chronic cardiovascular effects. 


\section{Introduction}

Hematolymphoid neoplasms are the leading cause of childhood cancer in the world ${ }^{1}$. Advances in pediatric cancer therapeutics have led patients to higher overall survival and increased adverse effects from their therapy ${ }^{2}$. The percentage of children with cancer with symptomatic cardiovascular toxicity ranges from $7 \%$ to $10 \%^{3}$. The cellular damage produced by antineoplastics in the heart muscle is well known ${ }^{4}$. Survivors of childhood cancer have an eight times higher risk of developing cardiovascular diseases throughout their lives ${ }^{5}$. High cumulative doses of anthracyclines and chest radiotherapy exposure are the main risk factors for heart failure. However, other triggers have been described: high doses of alkylating agents, female gender, age less than four years, having Down syndrome, and the Afro-descendant race ${ }^{6}$. We classified cardiac toxicity derived from cancer therapy according to the time of onset in the following categories: acute, when it occurs in the first week after exposure to the neoplastic agent; early-onset, which occurs between one week and up to a year after the end of antineoplastic treatment; and late-onset, that which occurs after one year of having finished treatment ${ }^{7,8}$. Despite the existence of guidelines for detecting and monitoring cardiovascular diseases in the adult population ${ }^{9}$, few evidence-based consensus or reviews provide recommendations for the diagnosis and follow-up of cardiovascular complications ${ }^{10}$ for patients with childhood cancer. Echocardiography is the primary diagnostic technique to evaluate the left ventricle's systolic performance by estimating its ejection fraction. Other cardiovascular evaluation tools are serum biomarkers such as troponin T, troponin I, Brain Natriuretic Peptide, and the electrocardiogram. ${ }^{7}$.

In a survival study of a cohort of children with acute lymphoblastic leukemia at a reference center for childhood cancer in Bogotá, a grade 3-4 cardiac toxicity frequency of $26.9 \%$ was found ${ }^{11}$. There are very few data on the frequency of cardiovascular complications derived from antineoplastic therapy in Colombian children.

The study's main objective was to describe the frequency of early cardiac involvement in children with acute leukemias who received antineoplastic treatment at a referral center for childhood cancer. Secondary objectives were to describe the echocardiographic and electrocardiographic findings and describing the serum biomarkers' behavior in the study group.

\section{Materials and Methods}

This is a prospective descriptive study, nested in a cohort of patients with a confirmed diagnosis of acute leukemias: acute lymphoid leukemia and acute myeloid leukemia, older than one year and younger than 18 years, in the period between October 1, 2017, and March 31,2019 . Participants were selected by non-probabilistic sequential convenience sampling of patients with a new diagnosis of acute lymphoblastic leukemia and acute myeloid leukemia.

\section{Inclusion criteria}

Patients older than 12 months and younger than 18 years with a new diagnosis of acute lymphoblastic leukemia and acute myeloid leukemia performed at HOMI Fundación Hospital de la Misericordia.

\section{Exclusion criteria}

Patients who did not start treatment at HOMI Fundación Hospital de la Misericordia.

Patients with a diagnosis of relapse of acute lymphoblastic leukemia or acute myeloid leukemia. Patient with a diagnosis of heart disease before the start of cancer treatment. Patients who did not complete at least two evaluations. Patients whose parents did not authorize their inclusion in the study. 


\section{Definitions}

The patients with acute lymphoid leukemia were classified according to their risk as standard, intermediate, and high. The risk classification for acute lymphoid leukemia is based on the ALLCI protocol of the BFM group (Appendix 1) ${ }^{12}$.

Cardiac dysfunction related to cancer therapy: the decrease in the left ventricle's systolic performance by estimating its ejection fraction below $53 \%$, by estimating with the biplane Simpson's method ${ }^{13,14}$.

Global longitudinal myocardial deformation: Considering the manufacturer of the echocardiography equipment used and the available literature, a deformation greater than $-20.1 \%$ was considered a normal absolute value for all age groups ${ }^{13,14}$.

A decrease in the percentage of deformation greater than $15 \%$ compared to the baseline value at follow-up was considered significant (global longitudinal myocardial deformation Delta) ${ }^{15}$.

Other associated cardiovascular disorders: coronary artery disease, arrhythmias, pericardial effusion, valve insufficiency (other than mild tricuspid or mitral regurgitation and considered physiological), thromboembolic disease, systemic arterial hypertension (defined as systolic or diastolic blood pressure higher than the 95th percentile for age, gender, and height), and pulmonary hypertension ${ }^{8}$ (defined as an echocardiographic estimate of a pulmonary systolic pressure greater than or equal to $40 \mathrm{mmHg}$ from the tricuspid regurgitation velocity and an estimate of pressure at the level of the right atrium in relation to the percentage of inferior vena cava collapse).

Acute toxicity: cardiovascular manifestations that appear in the first week of antineoplastic treatment ${ }^{7,8}$.

Early-onset toxicity: the appearance of cardiovascular manifestations after the first week and up to the first year after the end of treatment ${ }^{7,8}$.

Alterations in serum biomarkers: significant elevation of brain natriuretic peptide above 100 $\mathrm{pg} / \mathrm{mL}$ of TnI with a value greater than $0.05 \mathrm{in} \mathrm{ng} / \mathrm{L}$ and $\mathrm{TnT}$ value above $40 \mathrm{ng} / \mathrm{L}^{16}$.

Alterations in the electrocardiogram (ECG): identifying alterations in impulse generation, AV conduction (atrioventricular), IV conduction (interventricular), and repolarization disorders ${ }^{8}$.

Echocardiography evaluation: The taking and analysis of the echocardiographic studies were carried out by two pediatric cardiologists with more than five years of experience in evaluating patients with childhood cancer, performing ECG synchronized acquisitions ( 5 beats) for moving images. The three methods used to evaluate the systolic performance of the left ventricle were the ejection fraction (LVEF) estimated by the Simpson biplane method (LVEF (S)), the LVEF estimated by the Teicholz method (LVEF (T)), and the shortening fraction. An analysis of the global longitudinal strain was performed using the particle follow-up technique (Speckle tracking).

For quantifying the ejection fraction using the biplane Simpson method and the global longitudinal myocardial deformation analysis, the frames were obtained from the apical window in 4-chamber, 2-chamber, and three-chamber axes. The acquisition analysis was performed with the Phillips Affiniti 70C ultrasound machine software, version 1.7.1. For all cases, the operators located the basal points and the apical point to be analyzed in the three defined views, allowing automatic recognition of the endocardium in the first instance and manually correcting its location if necessary, using the editing function.

For the quantification of the ejection fractions by the Teicholz method and the shortening fraction, we used a static image acquired from the short axis of the ventricles. 

Prospective Study.

All patients underwent 12-lead ECG evaluations and two-dimensional (2D) echocardiography with the Phillips Affiniti 70C, 5-1, and 8-3 MHz transducers.

Assessments were performed with serum biomarkers measured in peripheral or central venous blood processed by rapid test immunochromatography. The serum biomarkers evaluated were brain natriuretic peptide, troponin $\mathrm{I}(\mathrm{TnI})$, and troponin $\mathrm{T}(\mathrm{TnT})$. The reference values correspond to the technique used.

All the previously mentioned evaluations (echocardiogram, electrocardiogram, and biomarkers) were performed before starting treatment and at specific points of the acute lymphoid leukemia and acute myeloid leukemia treatment (Figure 1). For patients with highrisk of the acute lymphoid leukemia, the end of treatment was considered the last evaluation at the end of reinduction or the last evaluation before hematopoietic stem cell transplantation. For patients with acute myeloid leukemia, the end of treatment was considered the last evaluation before TPH or the evaluation after three cycles of consolidation.

The cumulative doses of anthracyclines by pathology were converted to equivalent doses of doxorubicin: $1 \mathrm{mg}$ of daunorubicin is equivalent to $0.833 \mathrm{mg}$ of doxorubicin ${ }^{17}$.

\section{Statistical analysis}

According to the distribution after analysis with normality tests, the quantitative variables' statistical analyses were carried out with central tendency and dispersion measures, means, standard deviation, or medians and ranges, after analysis with normality tests (KolmogorovSmirnov or Shapiro Wilk) to establish the behavior of the data as parametric or nonparametric. Qualitative variables were analyzed with Pearson's $J i^{2}$ test and Fisher's exact test. The echocardiography data were analyzed according to the accumulated dose of anthracyclines. In each treatment group, the Wilcoxon test for nonparametric paired samples was used. For the

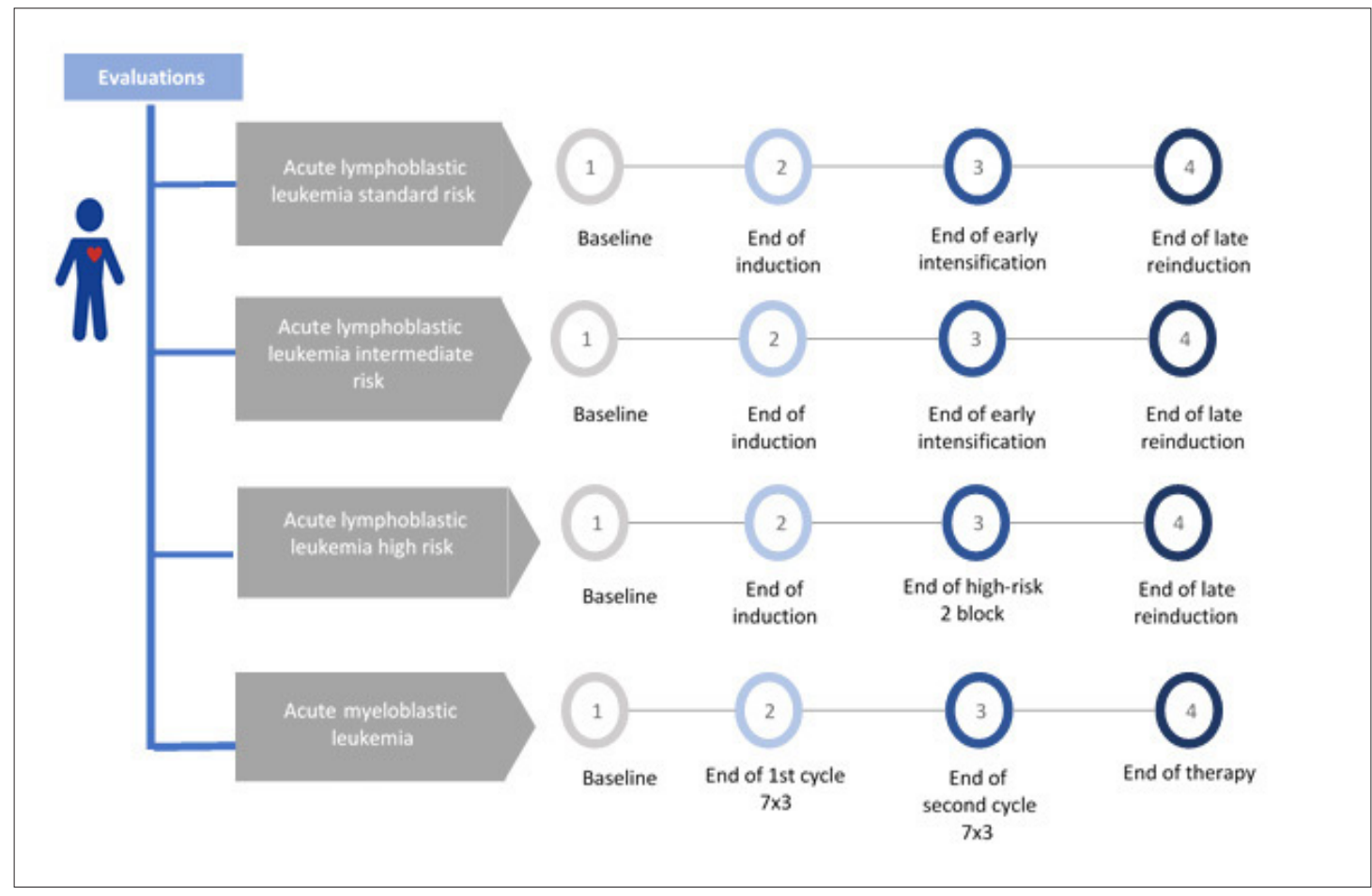

Figure 1. Study schema: time of evaluations with echocardiographic measurements, 12-lead electrocardiogram, and with biomarkers, according to type of leukemia. 
Table 1. Demographic characteristics of the study population.

\begin{tabular}{|c|c|c|c|c|c|}
\hline Variables & LLA RE & LLA RI & LLA RA & LMA & Total \\
\hline Number of patients (\%) & $14(12.5 \%)$ & $42(27.5 \%)$ & $38(33.9 \%)$ & $18(16 \%)$ & $112(100 \%)$ \\
\hline Median age in years (range) & $3.4(1-6)$ & $6.6(1.7-17.2)$ & $9.4(1.5-17.7)$ & $9.0(1.5-17.0)$ & $6.35(1.0-17.7)$ \\
\hline Female & $8(57.1 \%)$ & $17(40.5 \%)$ & $13(34.3 \%)$ & $7(38.9 \%)$ & $45(40.2 \%)$ \\
\hline Median weight in kilograms (range) & $12.8(10.9-25.0)$ & $20(10.4-74.0)$ & $19(10-73)$ & $31.5(10-69)$ & $20(10-74)$ \\
\hline Median height in cms (range) & $97(86-118)$ & $118.5(75-180)$ & $122.5(83-181)$ & $129(70-167)$ & $114(70-181)$ \\
\hline Accumulated dose of anthracycline $\mathrm{mg} / \mathrm{m} 2$ & 170 & 220 & 270 & 298 & NA \\
\hline
\end{tabular}

ALL: acute lymphoblastic leukemia, ER: standard risk, IR: intermediate risk, AR: high risk.

analysis of biochemical markers such as brain natriuretic peptide, patients were divided into two groups according to the presence or absence of cardiotoxicity and were analyzed with the Mann-Whitney U test for independent nonparametric samples. Statistical analysis was performed using the Statistical Package for Social Sciences (SPSS) for Windows, version 25.0. A value of $p<0.05$ was considered significant.

\section{Ethical aspects}

This study was classified as a "Minimal Risk" project. Informed consent was obtained from the parents of each patient. Assent was obtained from each of the patients or the patient's legal representative if that were the case. This research protocol was approved by the institutional ethics committee, act 4848 CEI-11-17.

\section{Results}

One hundred thirteen patients were admitted: 94 with acute lymphoid leukemia and 19 with acute myeloid leukemia. One patient with acute myeloid leukemia was excluded from the study because he did not have data from the second evaluation; the results correspond to 112 patients. We analyzed 38 patients (33.9\%) with high-risk acute lymphoblastic leukemia, 42 (37.5\%) with intermediate-risk, 14 (12.5\%) standard risk, and 18 patients with acute myeloid leukemia $(16.0 \%)$. Thirteen patients died during follow-up; data was collected until pre-death assessment. Table 1 describes the demographic characteristics of the study population.

Early-onset of cardiac dysfunction related to cancer therapy developed in 20 patients (17.9\%); no patient had acute heart disease.

There was early-onset toxicity in patients with acute lymphoid leukemia high-risk with a median of 30 days in 4 patients and $120 \mathrm{mg} / \mathrm{m}^{2}$ accumulated anthracyclines. By the third evaluation (end of intensification), eight patients presented early cardiotoxicity, with cumulative anthracyclines doses of $150 \mathrm{mg} / \mathrm{m}^{2}$. At the last evaluation (end of reinduction), a cumulative 11 patients had cardiac involvement with cumulative anthracycline doses of $270 \mathrm{mg} / \mathrm{m}^{2}$.

Cardiac dysfunction related to cancer therapy was found in two intermediate-risk patients with cumulative doses of $220 \mathrm{mg} / \mathrm{m}^{2}$ of doxorubicin at the end of reinduction. In the standard-risk group, no patients had cardiac dysfunction related to cancer therapy.

In the children with acute myeloid leukemia group, seven patients had early cardiotoxicity, one of them after $180 \mathrm{mg} / \mathrm{m}^{2}$ accumulated anthracyclines, and four patients after $298 \mathrm{mg} /$ $\mathrm{m}^{2}$ of anthracyclines. By the end of treatment, two additional patients had early heart disease. The decrease in LVEF (S) during follow-up, greater than ten percentage points compared to the previous LVEF (S), was a predictor for cardiotoxicity in patients with acute myeloid leukemia with an OR of 42.42 (95\% CI: 4.6- 391.0).

Abnormal findings on the echocardiogram were presented in 65 patients (Tables 2 and and33). 
Table 2. Alteraciones cardiovasculares de inicio temprano de acuerdo al tipo de leucemia.

\begin{tabular}{|c|c|c|c|c|c|}
\hline \multirow[b]{2}{*}{ Description of the heart condition } & \multicolumn{3}{|c|}{ Acute lymphoblastic leukemia } & \multirow{2}{*}{$\begin{array}{c}\text { Acute myeloid leukemia } \\
\text { n: } 18\end{array}$} & \multirow{2}{*}{$\begin{array}{l}\text { TOTAL } \\
\text { n: } 112\end{array}$} \\
\hline & $\begin{array}{c}\text { Standard risk } \\
\text { n: } 14\end{array}$ & $\begin{array}{c}\text { Intermediate risk n: } \\
\qquad 42\end{array}$ & $\begin{array}{l}\text { High risk } \\
\text { n: } 38\end{array}$ & & \\
\hline CDRCT (FEVI <53\%) & $0(0 \%)$ & $2(1.8 \%)$ & $11(9.8 \%)$ & $7(6.3 \%)$ & $20(17.9 \%)$ \\
\hline ECG abnormalities & $1(0.9 \%)$ & $16(14.3 \%)$ & $9(8.0 \%)$ & $* 5(4.4 \%)$ & $31(27.6 \%)$ \\
\hline Pericardial effusion & $2(1.8 \%)$ & 0 & $7(6.3 \%)$ & $* 5(4.5 \%)$ & $14(12.5 \%)$ \\
\hline Valvular insufficiency & 0 & 0 & $2(1.8 \%)$ & $\star 5(4.5 \%)$ & $7(6.2 \%)$ \\
\hline Arterial hypertension & $2(1.8 \%)$ & $5(4.5 \%)$ & $7(6.3 \%)$ & 0 & $14(12.5 \%)$ \\
\hline Pulmonary hypertension & $1(1.8 \%)$ & $5(4.5 \%)$ & $9(8.0 \%)$ & $2(1.8 \%)$ & $17(15.1 \%)$ \\
\hline No abnormal cardiovascular findings & $8(57.1 \%)$ & $9(21.4 \%)$ & $5(13.1 \%)$ & $5(27.7 \%)$ & $27(24.1 \%)$ \\
\hline
\end{tabular}

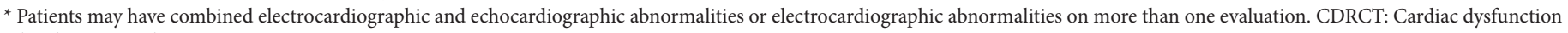
related to cancer therapy.

Table 3. Description of echocardiography values by type of leukemia and time of evaluation.

\begin{tabular}{|c|c|c|c|c|}
\hline High-risk acute lymphoblastic leukemia & $\begin{array}{l}\text { At diagnosis } \\
(\mathrm{n}=38)\end{array}$ & $\begin{array}{l}\text { At the end of induction } \\
\qquad(\mathrm{n}=38)\end{array}$ & $\begin{array}{l}\text { At the end of consolidation } \\
\qquad(n=30)\end{array}$ & $\begin{array}{l}\text { At the end of reinduction } \\
(n=17)\end{array}$ \\
\hline LVEF $(\mathrm{T})$ median (range) & $66.0(48-77)$ & $65.5(37-73)$ & $70.5(65-76)$ & $64.5(50-75)$ \\
\hline LVEF (S) median (range) & $63.5(46-70)$ & $54.0(42-73)$ & $62.5(60-65)$ & $64.7(53-67)$ \\
\hline FS median (range) & $36.0(23-46)$ & $35.0(17-41)$ & $39.0(34-44)$ & $34.5(25-43)$ \\
\hline TAPSE median (range) & $23(14-31)$ & $19(12-25)$ & $20(18-22)$ & $21(13-25)$ \\
\hline GLS median (range) & $-22.0(-30-18)$ & $-16.6(-22-15)$ & $-22.5(-23-22)$ & $-24.2(-26.3,-18.2)$ \\
\hline $\begin{array}{l}\text { Intermediate-risk acute lymphoblastic } \\
\text { leukemia }\end{array}$ & $\begin{array}{l}\text { At diagnosis } \\
\qquad(\mathrm{n}=42)\end{array}$ & $\begin{array}{l}\text { At the end of induction } \\
\qquad(\mathrm{n}=41)\end{array}$ & $\begin{array}{l}\text { At the end of consolidation } \\
\qquad(n=40)\end{array}$ & $\begin{array}{l}\text { At the end of reinduction } \\
\qquad(\mathrm{n}=36)\end{array}$ \\
\hline LVEF $(\mathrm{T})$ median (range) & $68.5(54-78)$ & $68.5(48-79)$ & $66.0(56-74)$ & $64.5(46-74)$ \\
\hline LVEF (S) median (range) & $62.9(53.8-74.0)$ & $62.1(54-71)$ & $63.0(54.8-76.0)$ & $62.1(48-75)$ \\
\hline FS median (range) & $37.0(27-46)$ & $37.3(24-46)$ & $36.0(29-43)$ & $34.1(22-42)$ \\
\hline TAPSE median (range) & $22.0(14-33)$ & $20.0(13.5-26.0)$ & $22.0(15-32)$ & $21.5(14-27)$ \\
\hline GLS median (range) & $-24.4(-30-18)$ & $-22.5(-27.5,-17.2)$ & $-23.3(-31.0-19.6)$ & $-22.7(-28.0,-17.4)$ \\
\hline Standard-risk acute lymphoblastic leukemia & $\begin{array}{l}\text { At diagnosis } \\
(n=14)\end{array}$ & $\begin{array}{l}\text { At the end of induction } \\
\qquad(n=14)\end{array}$ & $\begin{array}{l}\text { At the end of consolidation } \\
\qquad(n=14)\end{array}$ & $\begin{array}{l}\text { At the end of reinduction } \\
\qquad(n=14)\end{array}$ \\
\hline LVEF $(\mathrm{T})$ median (range) & $65.5(40-74)$ & $70.0(57-77)$ & $65.0(58-72)$ & $63.0(60-72)$ \\
\hline LVEF (S) median (range) & $60.2(38-65)$ & $58.6(55-63,3)$ & $60.0(54.7-67.7)$ & $59.0(55.7-67.2)$ \\
\hline FS median (range) & $34.5(19-43)$ & $38.5(29-44)$ & $35.0(30-40)$ & $33.0(31-40)$ \\
\hline TAPSE median (range) & $19.5(16-23)$ & $19.0(16-25)$ & $20.0(16-27)$ & $18.0(12-23)$ \\
\hline GLS median (range) & $-23.4(-26.6,-16.8)$ & $-21.3(-25.9,-16.3)$ & $-24.1(-26.7,-20.0)$ & $-23.2(-31,-19)$ \\
\hline Acute Myeloid Leukemia & $\begin{array}{l}\text { At diagnosis } \\
n=18\end{array}$ & $\begin{array}{l}\text { At the end of } 7+3 \text { (1st cycle) } \\
n=18\end{array}$ & $\begin{array}{l}\text { Al finalizar } 7+3\left(2^{\circ} \text { ciclo }\right) \\
n=18\end{array}$ & $\begin{array}{l}\text { At the end of treatment } \\
\qquad n=16\end{array}$ \\
\hline LVEF (T) median (range) & $68.0(64-77)$ & $68.0(54-76)$ & $64.0(38-70)$ & $63.0(43-73)$ \\
\hline LVEF (S) median (range) & $62.2(55,5-74,3)$ & $63.0(52.2-69.8)$ & $58.8(32-71)$ & $59.9(41.0-64.4)$ \\
\hline FS median (range) & $37.0(34-48)$ & $38.0(27-42)$ & $33.0(18-38)$ & $34.0(21-42)$ \\
\hline TAPSE median (range) & $22.0(13-32)$ & $21.0(13-31)$ & $22.0(14-31)$ & $21.0(12-30)$ \\
\hline GLS median (range) & $-21(-30-15)$ & $-21.2(-26.8,-17.4)$ & $-21.5(-27.0,-15.8)$ & $-22.6(-26.1,-16.1)$ \\
\hline
\end{tabular}

LVEF(T): left ventricular ejection fraction Teicholz method, LVEF (S): left ventricular ejection fraction Simpson method, FS: fraction shortening, TAPSE: tricuspid annular, plane systolic excursion, GLS: global longitudinal strain.

The most common ECG abnormalities were impulse generation disturbances and repolarization disorders (Appendix 2). There were no events of thromboembolism, peripheral vascular disease, coronary disease, or stroke.

It can be seen in Figure 2 how the LVEF evaluated with the Simpson method decreases from the start of treatment as the accumulated doses of anthracyclines are given. It is significant with values of accumulate anthracycline dose over $150 \mathrm{mg} / \mathrm{m}^{2}$ (Figure 2).

In patients with high-risk leukemia, the factors related to cardiotoxicity were the presence of systemic arterial hypertension at any time of treatment with an OR: 8.57 (IC 95\%: 1.3554.35) $p: 0.022$, pulmonary hypertension with an OR: 4.11 (IC 95\%: 1.12-15.05) $p: 0.038$, the global longitudinal myocardial deformation delta (global longitudinal myocardial deformation 

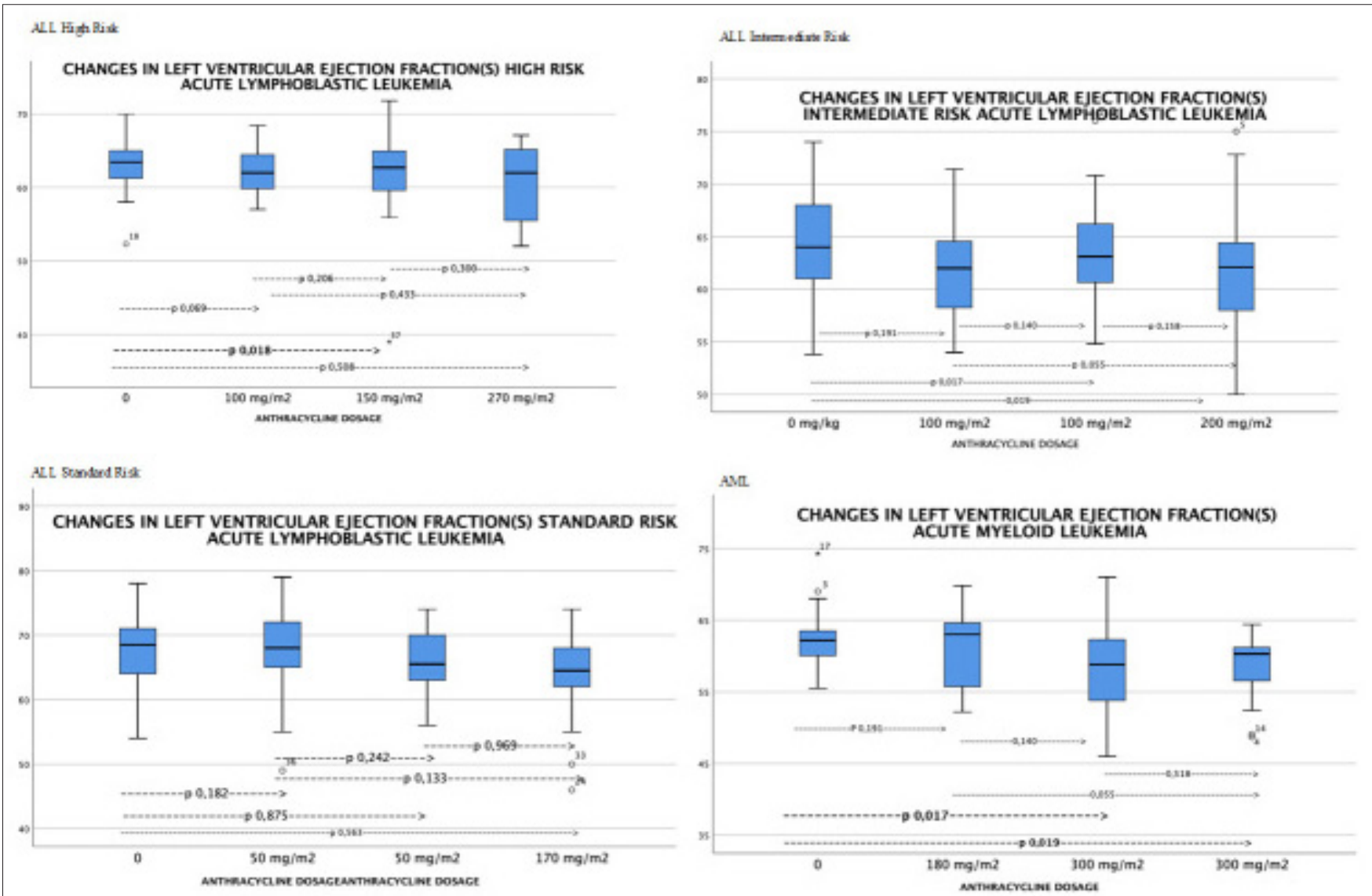

Figure 2. Changes in left ventricular ejection fraction by Simpson method by type of leukemia (evaluated with Wilcoxon test, statistically significant differences $p<0.05)$.

difference greater than 15\%) with an OR: 19.5 (CI 95\%: 4.57-83.09) $p<0.000$ and the decrease in LVEF (S) by more than ten percentage points with respect to the baseline evaluation by echocardiogram, with an OR: 56 (CI 95\%: 6.31- 496) $p<0.000$.

When performing the Wilcoxon test analysis for paired samples, a statistically significant difference was observed for LVEF (S) p: 0.018 and global longitudinal myocardial deformation $p$ : 0.004 between the baseline echocardiogram evaluation and the evaluation after receiving $150 \mathrm{mg} / \mathrm{m}^{2}$ of doxorubicin.

\section{Serum biomarker analysis}

No relationship was observed between the presence of cardiac involvement and alteration in TnI or TnT (Appendix 3).

Acute lymphoid leukemia standard risk: no patient presented elevation in serum biomarkers throughout all evaluations.

Acute lymphoid leukemia intermediate risk: $69 \%$ of patients with acute lymphoid leukemia intermediate-risk had no abnormality in serum biomarkers. There was an elevation of brain natriuretic peptide in 12 patients (29.3\%), 11 after intensification, and one patient in the endof-treatment evaluation.

In two patients with altered biomarkers, an associated repolarization disorder was found, without echocardiographic manifestations. Elevation of TnT was found in one patient; in the last evaluation, this patient presented LVEF $<53 \%$ asymptomatic. 
Acute lymphoid leukemia high risk: There was no alteration in TnT or TnI. In 8 patients $(24.2 \%)$, brain natriuretic peptide elevation $>100 \mathrm{pg} / \mathrm{mL}$ was found during the study. One patient with elevated brain natriuretic peptide at the end of induction had a severe infection associated with it. At the time of the third evaluation (at the end of the second high-risk block 2), three patients presented elevation of brain natriuretic peptide secondary to cardiomyopathy in the clinical context of infection; in 2 patients, an elevation not related to infection was found. At the last evaluation, two patients had elevated brain natriuretic peptide, none related to infection or sepsis.

Acute myeloid leukemia: No patient presented alterations in troponin T or troponin I. Regarding brain natriuretic peptide, one patient presented elevation at diagnosis with recovery to normal values during follow-up, two presented elevation in the third evaluation (after the second $7+3$ cycle), and three at the end of the treatment, one of them persisted with the abnormal value from the previous measurement.

\section{Discussion}

Cardiovascular compromise is the most frequent adverse effect, with a deterioration in the quality and life expectancy of children cured of acute leukemias ${ }^{18,19}$. The prospective methodology of this study allowed the real-time evaluation of the identification of earlyonset cardiovascular compromise. Few prospective studies evaluate this complication; a critical aspect for identifying and reporting early toxicity is the difference in times used by the different authors ${ }^{19,20}$.

Early-onset toxicity was found in $13.5 \%$ of patients with acute lymphoid leukemia highrisk ${ }^{21}$, very similar to that found by Lipschultz et al. ${ }^{19}$, who found $10 \%$ within the first year of exposure to anthracyclines. In this study, acute lymphoid leukemia high-risk patients presented cardiotoxicity with $150 \mathrm{mg} / \mathrm{m}^{2}$ anthracycline cumulative doses at a median of 99 days. This lower frequency is similar to that reported by Militaru et al's prospective study, which found an LVEF drop below $50 \%$ in $28.5 \%$ of children with acute lymphoid leukemia at three months of treatment ${ }^{22}$. It is not clear why the difference in the incidence of this condition with a similar evaluation period. There is an association between the accumulated dose of anthracycline and cardiomyopathy. A greater probability is reported with an accumulated dose $>250 \mathrm{mg} / \mathrm{m}^{2}$, however, there is evidence of toxicity at doses starting at 45 $\mathrm{mg} / \mathrm{m}^{223,24}$. During this cohort's follow-up, no patient presented toxicity with doses lower than $50 \mathrm{mg} / \mathrm{m}^{2}$. Therefore, echocardiographic surveillance of patients with higher doses of anthracyclines must be carried out throughout treatment.

In the follow-up of childhood cancer survivors exposed to anthracyclines, estimating myocardial deformation and its changes over time exposed to chemotherapy can predict the appearance of cardiac dysfunction related to cancer therapy ${ }^{14,25,26}$. Despite the heterogeneity in the data regarding the age of the patient, the type of cancer, and the evaluation techniques used, a meta-analysis found that changes in myocardial deformation precede changes in LVEF in exposed patients to anthracyclines, even at doses lower than those historically thought to be cardiotoxic ${ }^{27}$. Oikonomou et al. ${ }^{28}$ defined an abnormal absolute value of the global longitudinal myocardial deformation between -18 and -19\% (with General Electric platforms), a cut-off point associated with cardiac dysfunction related to cancer therapy with an OR: 12.27 (CI 95\%: 7.73-19.47); this is similar to what was found in the cohort of our study. The evidence of alterations in global longitudinal myocardial deformation is strong in favor of predicting the subsequent decrease in LVEF at diagnostic values of cardiac dysfunction related to cancer therapy (less than 53\%), and that is why international guidelines have adopted the concept of subclinical left ventricular dysfunction in those patients with an LVEF greater than 53\% but with a decrease in myocardial deformation (global longitudinal myocardial deformation delta) greater than $15 \%$ with respect to the baseline evaluation ${ }^{8.14}$. Our study found that patients with acute lymphoid leukemia high-risk with global longitudinal myocardial deformation delta more than $15 \%$ had cardiac dysfunction related to cancer therapy. 

Prospective Study.

The fall in LVEF (S) by more than ten percentage points, but less than $53 \%$, constituted the leading risk factor for cardiac dysfunction related to cancer therapy in the population analyzed in this study. The vast majority of consensuses consider that a reduction in LVEF between $10 \%$ and $20 \%$ in asymptomatic patients is not a sufficiently sensitive parameter to define cardiac dysfunction ${ }^{27-29}$. Early identification of echocardiographic abnormalities described (defined as predictors of cardiac dysfunction related to cancer therapy) potentially makes it possible to identify patients with a higher risk of developing heart failure over time. The use of medications such as angiotensin-converting enzyme (ACE) inhibitors, beta-blockers ${ }^{30,31}$, and the use of cardioprotection ${ }^{32}$ could be considered.

In this study, the measurement of the left ventricular ejection fraction by the Teicholz method was compared with the biplane Simpson method, finding that the Teicholz method overestimated baseline LVEF compared to the biplane Simpson method, this is explained by its geometric assumptions and its regional rather than global character in the assessment of LVEF ${ }^{17,30}$. Most consensuses recommend using the biplane Simpson method in 2D echocardiography since it has a better correlation with the current method of choice for estimating LVEF: 3D echocardiography ${ }^{17}$. Unfortunately, the use of the Simpson biplane method in pediatric oncology centers in the country is scarce.

No relationship was found between echocardiogram and ECG findings in patients with cardiac dysfunction, similar to that described by Pourier et al. ${ }^{33}$, who found no association between these two diagnostic tests in childhood cancer survivors in a 5-year follow-up. Few studies on children define electrocardiographic alterations related to early-onset cardiac dysfunction. Most publications describe the late effects associated with the use of anthracyclines ${ }^{34}$. Arrhythmias are more frequent in adults undergoing antineoplastic drugs with pre-existing cardiovascular diseases than in children who have transient rhythm disturbances ${ }^{35}$.

In this study, no relationship was found with female gender and age at diagnosis less than four years old, referenced in the literature as risk factors for cardiac toxicity associated with the use of antineoplastic drugs. ${ }^{36-38}$.

A higher incidence of cardiac toxicity was recorded in the group of patients with acute lymphoid leukemia for whom systemic arterial hypertension or pulmonary hypertension was documented in the follow-up and in the group of acute myeloid leukemia in whom pulmonary hypertension was found than in patients without these findings. This difference was statistically significant, unlike those reported in the literature on the low association of HTN and PHT with cardiac toxicity in the pediatric population ${ }^{6}$.

In this study, no significant difference was documented between alterations in the cardiac biomarkers evaluated and the appearance of cardiac dysfunction related to cancer therapy or as predictors of it. This contrasts with the findings of the systematic review of the literature by Dolci et al. ${ }^{39}$, who found that troponin T's elevation could predict the appearance of left ventricular dysfunction up to three months before the appearance of clinical manifestations of cardiomyopathy.

No association was found between the elevation of brain natriuretic peptide and the cumulative dose of anthracyclines or cardiotoxicity in acute lymphoid leukemia patients. Armenian et al. ${ }^{40}$ suggest using brain natriuretic peptide and troponins in symptomatic patients and not as predictors of toxicity.

One limitation of this study is that not all the patients completed the follow-up due to the disease's circumstances; the variability between the echocardiography equipment and software means that the results found are applied to the patients evaluated with the technology methodology described. 


\section{Conclusions}

Comprehensive cardiovascular evaluation and monitoring of patients with acute leukemias are essential, taking into account the high incidence of alterations in this system that in the short and long term can affect the quality of life and survival of these patients. In this study, the main risk predictors for cardiac dysfunction related to cancer therapy were a fall in LVEF of 10 percentage points (to values higher than 53\%), alteration of global longitudinal myocardial deformation (absolute value and delta of global longitudinal myocardial deformation), and the presence of pulmonary and arterial hypertension. The timely identification of predictors of cardiac dysfunction in the pediatric population undergoing cancer therapy makes it possible to prevent complications and sequelae.

\section{References}

1. Steliarova-Foucher E, Colombet M, Ries LAG, Moreno F, Dolya A, Bray F, et al. International incidence of childhood cancer, 2001-10: a population-based registry study. Lancet Oncol. 2017;18(6):719-31. Doi: 10.1016/ S1470-2045(17)30186-9.

2. Lancellotti P, Nkomo VT, Badano LP, Bergler-Klein J, Bergler J, Bogaert J, et al. Expert consensus for multi-modality imaging evaluation of cardiovascular complications of radiotherapy in adults: a report from the European Association of Cardiovascular Imaging and the American Society of Echocardiography. J Am Soc Echocardiogr. 2013;26(9):1013-32. Doi: 10.1016/j.echo.2013.07.005

3. Pignatelli RH, Ghazi P, Reddy SC-B, Thompson P, Cui Q, Castro J, et al. Abnormal myocardial strain indices in children receiving anthracycline chemotherapy. Pediatr Cardiol. 2015;36(8):1610-6. Doi: 10.1007/s00246015-1203-8

4. Kim H, Kang HJ, Park KD, Koh K-N, Im HJ, Seo JJ, et al. Risk factor analysis for secondary malignancy in dexrazoxane-treated pediatric cancer patients. Cancer Res Treat Off J Korean Cancer Assoc. 2019;51(1):35767. Doi: $10.4143 /$ crt.2017.457

5. Tukenova M, Guibout C, Oberlin O, Doyon F, Mousannif A, Haddy N, et al. Role of cancer treatment in long-term overall and cardiovascular mortality after childhood cancer. J Clin Oncol. 2010;28(8):1308-15. Doi: 10.1200/JCO.2008.20.2267

6. Chow EJ, Chen Y, Kremer LC, Breslow NE, Hudson MM, Armstrong GT, et al. Individual prediction of heart failure among childhood cancer survivors. J Clin Oncol. 2015;33(5):394-402. Doi: 10.1200/JCO.2014.56.1373

7. Harake D, Franco VI, Henkel JM, Miller TL, Lipshultz SE. Cardiotoxicity in childhood cancer survivors: strategies for prevention and management. Future Cardiol. 2012;8(4):647-70. Doi: 10.2217/fca.12.44

8. Zamorano JL, Lancellotti P, Rodriguez Muñoz D, Aboyans V, Asteggiano R, Galderisi M, et al. 2016 ESC Position Paper on cancer treatments and cardiovascular toxicity developed under the auspices of the ESC Committee for Practice Guidelines: The Task Force for cancer treatments and cardiovascular toxicity of the European Society of Cardiology (ESC). Eur Heart J. 2016;37(36):2768-801. Doi: 10.1093/eurheartj/ehw211

9. Yancy CW, Jessup M, Bozkurt B, Butler J, Casey DE, Colvin MM, et al. 2017 ACC/AHA/HFSA focused update of the 2013 ACCF/AHA guideline for the management of heart failure: a report of the American College of Cardiology/American Heart Association Task Force on Clinical Practice Guidelines and the Heart Failure Society of America. Circulation. 2017;136(6):e137-61. Doi: 10.1161/CIR.0000000000000509

10. Sieswerda E, Postma A, van Dalen EC, van der Pal HJH, Tissing WJE, Rammeloo LAJ, et al. Late effects of childhood cancer task force of the Dutch Childhood Oncology Group (DCOG LATER). The Dutch Childhood 

Prospective Study.

Oncology Group guideline for follow-up of asymptomatic cardiac dysfunction in childhood cancer survivors. Ann Oncol. 2012; 23(8): 2191-2198. Doi: 10.1093/annonc/mdr595

11. Trujillo ÁM, Linares A, Sarmiento IC, Trujillo ÁM, Linares A, Sarmiento IC. Intensive chemotherapy in children with acute lymphoblastic leukemia. Interim analysis in a referral center in Colombia. Rev Fac Med. 2016;64(3):417-25. Doi: 10.15446/revfacmed.v64n3.53961

12. Stary J, Zimmermann M, Campbell M, Castillo L, Dibar E, Donska S, et al. Intensive chemotherapy for childhood acute lymphoblastic leukemia: results of the randomized intercontinental trial ALL IC-BFM 2002. J Clin Oncol. 2014;32(3):174-84.

13. Perez IE, Alam CT, Hernandez GA and Sanchassani R. Cancer therapy-related cardiac dysfunction: an overview for the clinician. Clin Med Insights Cardiol. 2019; 13: 1-11. Doi: 10.1177/1179546819866445

14. Plana JC, Galderisi M, Barac A, Ewer MS, Ky B, Scherrer-Crosbie M, et al. Expert consensus for multimodality imaging evaluation of adult patients during and after cancer therapy: a report from the American Society of Echocardiography and the European Association of Cardiovascular Imaging. J Am Soc Echocardiogr. 2014;27(9):911-39 Doi: 10.1016/j.echo.2014.07.012

15. Levy PT, Machefsky A, Sanchez AA, Patel MD, Rogal S, Fowler S, et al. Reference ranges of left ventricular strain measures by two-dimensional speckle-tracking echocardiography in children: a systematic review and meta-analysis. J Am Soc Echocardiogr. 2016;29(3):209-225.e6. Doi: 10.1016/j.echo.2015.11.016

16. Santaló Bel M, Guindo Soldevila J, Ordóñez Llanos J. Marcadores biológicos de necrosis miocárdica. Rev Esp Cardiol. 2003;56(7):703-20. Doi: 10.1016/S0300-8932(03)76942-5

17. Feijen EAM, Leisenring WM, Stratton KL, Ness KK, van der Pal HJH, van Dalen EC, et al. Derivation of Anthracycline and Anthraquinone equivalence ratios to Doxorubicin for late-onset cardiotoxicity. JAMA Oncol. 2019;5(6):864-71. Doi: 10.1001/jamaoncol.2018.6634

18. Bansal N, Amdani SM, Hutchins KK, Lipshultz SE. Cardiovascular disease in survivors of childhood cancer. Curr Opin Pediatr. 2018;30(5):628-38. Doi: 10.1097/MOP.0000000000000675

19. Lipshultz SE, Colan SD, Gelber RD, et al. Late cardiac effects of doxorubicin therapy for acute lymphoblastic leukemia i childhood. N Engl J Med. 1991; 324: 808-815. Doi: 10.1056/NEJM199103213241205

20. Mavinkurve-Groothuis AM, Marcus KA, Pourier M, Loonen J, Feuth T, Hoogerbrugge PM, et al. Myocardial 2D strain echocardiography and cardiac biomarkers in children during and shortly after anthracycline therapy for acute lymphoblastic leukaemia (ALL): a prospective study. Eur Heart J Cardiovasc Imaging. 2013;14(6):562-9. Doi: 10.1093/ehjci/jes217

21. Giantris A, Lipshultz S, Abdurrahman L, Hinkle A, Asselin B. Anthracycline-induced cardiotoxicity in children and young adults. Crit Rev Oncol Hematol. 1998;27(1):53-68. Doi: 10.1016/S1040-8428(97)10007-5

22. Militaru A, Zus S, Cimpean AM, lurciuc S, Matusz P, lurciuc M, et al. Early diagnosis of cardiotoxicity in patients undergoing chemotherapy for acute lymphoblastic leukemia. Anticancer Res. 2019;39(6):3255-64. Doi: 10.21873/anticanres. 13467

23. Lipshultz SE, Lipsitz SR, Sallan SE, Dalton VM, Mone SM, Gelber RD, et al. Chronic progressive cardiac dysfunction years after doxorubicin therapy for childhood acute lymphoblastic leukemia. J Clin Oncol Off J Am Soc Clin Oncol. 2005;23(12):2629-36. Doi: 10.1200/JCO.2005.12.121

24. Leger K, Slone T, Lemler M, Leonard D, Cochran C, Bowman WP, et al. Subclinical cardiotoxicity in childhood cancer survivors exposed to very low dose anthracycline therapy. Pediatr Blood Cancer. 2015;62(1):123-7. Doi: 10.1002/pbc.25206 

Prospective Study.

25. Mavinkurve-Groothuis AMC, Groot-Loonen J, Marcus KA, Bellersen L, Feuth T, Bökkerink JPM, et al. Myocardial strain and strain rate in monitoring subclinical heart failure in asymptomatic long-term survivors of childhood cancer. Ultrasound Med Biol. 2010;36(11):1783-91. Doi: 10.1016/j.ultrasmedbio.2010.08.001

26. Motoki H, Koyama J, Nakazawa H, Aizawa K, Kasai H, Izawa A, et al. Torsion analysis in the early detection of anthracycline-mediated cardiomyopathy. Eur Heart J Cardiovasc Imaging. 2012;13(1):95-103. Doi: 10.1093/ ejechocard/jer172

27. Thavendiranathan P, Poulin F, Lim K-D, Plana JC, Woo A, Marwick TH. Use of myocardial strain imaging by echocardiography for the early detection of cardiotoxicity in patients during and after cancer chemotherapy: a systematic review. J Am Coll Cardiol. 2014;63(25 Pt A):2751-68. Doi: 10.1016/j.jacc.2014.01.073

28. Oikonomou EK, Kokkinidis DG, Kampaktsis PN, Amir EA, Marwick TH, Gupta D, et al. Assessment of prognostic value of left ventricular global longitudinal strain for early prediction of chemotherapy-induced cardiotoxicity: a systematic review and meta-analysis. JAMA Cardiol. 2019;4(10):1007-18. Doi: 10.1001/ jamacardio.2019.2952

29. Curigliano G, Lenihan D, Fradley M, Ganatra S, Barac A, Blaes A, et al. Management of cardiac disease in cancer patients throughout oncological treatment: ESMO consensus recommendations. Ann Oncol Off J Eur Soc Med Oncol. 2020;31(2):171-90 Doi: 10.1016/j.annonc.2019.10.023

30. Avila MS, Ayub-Ferreira SM, de Barros Wanderley MR, das Dores Cruz F, Gonçalves Brandão SM, Rigaud VOC, et al. Carvedilol for prevention of chemotherapy-related cardiotoxicity: The CECCY Trial. J Am Coll Cardiol. 2018;71(20):2281-90. Doi: 10.1016/j.jacc.2018.02.049

31. Cardinale D, Colombo A, Sandri MT, Lamantia G, Colombo N, Civelli M, et al. Prevention of high-dose chemotherapy-induced cardiotoxicity in high-risk patients by angiotensin-converting enzyme inhibition. Circulation. 2006;114(23):2474-81. Doi: 10.1161/CIRCULATIONAHA.106.635144

32. Reichardt P, Tabone M-D, Mora J, Morland B, Jones RL. Risk-benefit of dexrazoxane for preventing anthracycline-related cardiotoxicity: re-evaluating the European labeling. Future Oncol Lond Engl. 2018;14(25):2663-76. Doi: 10.2217/fon-2018-0210

33. Pourier MS, Mavinkurve-Groothuis AMC, Loonen J, Bökkerink JPM, Roeleveld N, Beer G, et al. Is screening for abnormal ECG patterns justified in long-term follow-up of childhood cancer survivors treated with anthracyclines?. Pediatr Blood Cancer. 2017;64(3). Doi: 10.1002/pbc.26243

34. Kocabas A, Kardelen F, Ertug H, Aldemir-Kocabas B, Tosun Ö, Yesilipek A, et al. Assessment of earlyonset chronic progressive anthracycline cardiotoxicity in children: different response patterns of right and left ventricles. Pediatr Cardiol. 2014;35(1):82-8. Doi: 10.1007/s00246-013-0745-x

35. Bansal N, Blanco JG, Sharma UC, Pokharel S, Shisler S, Lipshultz SE. Cardiovascular diseases in survivors of childhood cancer. Cancer Metastasis Rev. 2020;39(1):55-68. Doi: 10.1007/s10555-020-09859-w

36. Lipshultz SE, Lipsitz SR, Mone SM, Goorin AM, Sallan SE, Sanders SP, et al. Female sex and higher drug dose as risk factors for late cardiotoxic effects of doxorubicin therapy for childhood cancer. N Engl J Med. 1995; 332(26):1738-43. Doi: 10.1056/NEJM199506293322602

37. Bansal N, Amdani S, Lipshultz ER, Lipshultz SE. Chemotherapy-induced cardiotoxicity in children. Expert Opin Drug Metab Toxicol. 2017;13(8):817-32. Doi: 10.1080/17425255.2017.1351547

38. Hildebrandt MAT, Reyes M, Wu X, Pu X, Thompson KA, Ma J, et al. Hypertension Susceptibility Loci are Associated with Anthracycline-related Cardiotoxicity in Long-term Childhood Cancer Survivors. Sci Rep. 2017;7(1):9698. Doi: 10.1038/s41598-017-09517-2 

Prospective Study.

39. Dolci A, Dominici R, Cardinale D, Sandri MT, Panteghini M. Biochemical markers for predicting chemotherapy-induced cardiotoxicity: systematic review of the literature and recommendations for use. $\mathrm{G}$ Ital Cardiol. 2006. 2006;7(9):604-11.

40. Armenian SH, Hudson MM, Mulder RL, Chen MH, Constine LS, Dwyer M, et al. Recommendations for cardiomyopathy surveillance for survivors of childhood cancer: a report from the International Late Effects of Childhood Cancer Guideline Harmonization Group. Lancet Oncol. 2015; 16(3): e123-136. Doi: 10.1016/S14702045(14)70409-7 


\section{Appendix 1}

Risk classification of patients with acute lymphoid leukemia.

\begin{tabular}{|c|c|c|c|}
\hline Characteristics & Standard risk & Intermediate risk & High risk \\
\hline Age at diagnosis & $>1$ year and $<6$ years & $>1$ year and $<6$ years & Any age \\
\hline Leukocytes at diagnosis & $<20,000 /(\mathrm{L}$ & $>20,000 /(\mathrm{L}$ & Any leukocyte count \\
\hline Response to steroids at day 15 & Blasts $<1,000 /(\mathrm{L}$ & Blasts $<1,000 /(\mathrm{L}$ & Blasts $>1,000 /(\mathrm{L}$ \\
\hline $\begin{array}{l}\text { Minimal residual bone marrow } \\
\text { disease at day } 15\end{array}$ & $<0.1 \%$ & $<10 \%$ & $>10 \%$ \\
\hline Bone marrow at day 15 & M1 or M2 & M1 or M2 & M3 \\
\hline Bone marrow at day 33 & M1 & M1 & M2 or M3 \\
\hline Molecular biology & $\begin{array}{l}\text { Negative for } \mathrm{t}(9: 22)(\mathrm{BCR} / \mathrm{ABL}) \text { or } \\
\mathrm{t}(4: 11)(\mathrm{MLL} / \mathrm{AF} 4)\end{array}$ & $\begin{array}{l}\text { Negative for } \mathrm{t}(9: 22)(\mathrm{BCR} / \mathrm{ABL}) \text { or } \\
\mathrm{t}(4: 11)(\mathrm{MLL} / \mathrm{AF} 4)\end{array}$ & $\begin{array}{c}\text { Positive for } \mathrm{t}(9: 22) \text { (BCR/ABL) or } \\
\mathrm{t}(4: 11) \text { (MLL/AF4) or hypodiploidy } \\
<45 \text { chromosomes }\end{array}$ \\
\hline
\end{tabular}

Source: table of own elaboration. M1 = <5\% blasts by morphology, M2 => 5\% and $<25 \%$ blasts by morphology, M3 => 25\% blasts by morphology.

\section{Appendix 2}

Electrocardiographic alterations found in patients with early-onset condition, by type of leukemia and stage of evaluation.

\begin{tabular}{|c|c|c|c|c|}
\hline & At diagnosis $(n=38)$ & $\begin{array}{l}\text { At the end of induction }(\mathrm{n}= \\
\text { 37) DAA } 100 \mathrm{mg} / \mathrm{m} 2 \text {. }\end{array}$ & $\begin{array}{l}\text { End of intensification }(\mathbf{n}= \\
\text { 27) DAA } 150 \mathrm{mg} / \mathrm{m} 2 .\end{array}$ & $\begin{array}{l}\text { At the end of reinduction (n } \\
=17) \text { DAA270 } \mathrm{mg} / \mathrm{m} 2 \text {. }\end{array}$ \\
\hline $\begin{array}{l}\text { High risk acute } \\
\text { lymphoblastic leukemia }\end{array}$ & $\mathbf{n}=38$ & $\mathbf{n}=\mathbf{3 7}$ & $\mathrm{n}=27$ & $\mathbf{n}=17$ \\
\hline \multicolumn{5}{|l|}{ Electrocardiographic Alterations } \\
\hline Pulse generation & 2 & 1 & 1 & 0 \\
\hline Intraventricular conduction & 0 & 2 & 2 & 0 \\
\hline Repolarization disorders & 2 & 0 & 0 & 3 \\
\hline Arrhythmias & 0 & S1, Q3, T3 AV block^ grade 1 & & \\
\hline $\begin{array}{l}\text { Intermediate risk acute } \\
\text { lymphoblastic leukemia }\end{array}$ & $n=42$ & $n=41$ & $n=40$ & $n=36$ \\
\hline \multicolumn{5}{|l|}{ Electrocardiographic Alterations } \\
\hline Pulse generation & 2 & 2 & 1 & 0 \\
\hline Intraventricular conduction & 2 & 0 & 3 & 4 \\
\hline Repolarization disorders & 1 & 0 & 3 & 3 \\
\hline Arrhythmias & 0 & $\begin{array}{l}2 \text { arrhythmias: low atrial } \\
\text { rhythm }\end{array}$ & 1 block AV grade 11 without & $\begin{array}{l}1 \text { right branch block } 1 \text { TSV } \\
1 \text { repolarization disorder }\end{array}$ \\
\hline $\begin{array}{l}\text { Standard risk acute lympho- } \\
\text { blastic leukemia }\end{array}$ & $\mathrm{n}=14$ & $n=14$ & $n=13$ & $n=13$ \\
\hline \multicolumn{5}{|l|}{ Electrocardiographic Alterations } \\
\hline Pulse generation & 1 & 0 & 0 & 0 \\
\hline Intraventricular conduction & 0 & 0 & 0 & 0 \\
\hline Repolarization disorders & 0 & 1 & 0 & 0 \\
\hline Arrhythmias & 0 & 1 without data & 1 without data & 0 \\
\hline Acute myeloid leukemia & $\mathrm{n}=18$ & $\begin{array}{c}\text { At the end 7x3 (1) DAA } 149 \\
\text { mg / m2. }\end{array}$ & $\begin{array}{l}\text { At the end of cycle } 7 \times 3 \text { (2) } \\
\text { DAA } 149 \mathrm{mg} / \mathrm{m} 2 .\end{array}$ & $\begin{array}{l}\text { At the end of treatment } \\
\text { DAA } 298 \mathrm{mg} / \mathrm{m} 2 \text {. }\end{array}$ \\
\hline \multicolumn{5}{|l|}{ Electrocardiographic Alterations } \\
\hline Pulse generation & 0 & 1 & 2 & 0 \\
\hline Repolarization disorders & 1 & 2 & 0 & 3 \\
\hline Arrhythmias & 0 & $\begin{array}{l}1 \text { patient with right bundle } \\
\text { branch block }\end{array}$ & $\begin{array}{l}1 \text { patient with low atrial } \\
\text { rhythm }\end{array}$ & $\begin{array}{l}1 \text { patient with low atrial } \\
\text { rhythm }\end{array}$ \\
\hline
\end{tabular}




\section{Appendix 3}

Table of troponin results by type of leukemia and stage of evaluation.

\begin{tabular}{|c|c|c|c|c|}
\hline & At diagnosis & At the end of induction & End of intensification & At the end of reinduction \\
\hline $\begin{array}{l}\text { High risk acute } \\
\text { lymphoblastic leukemia }\end{array}$ & $\mathrm{n}=38$ & $\mathbf{n}=37$ & $\mathrm{n}=\mathbf{2 7}$ & $\mathbf{n}=\mathbf{1 7}$ \\
\hline $\begin{array}{l}\text { Troponina T } \\
\text { Menor de } 40 \\
\text { Troponina I }\end{array}$ & 38 & 37 & 26,1 paciente 47 & 17 \\
\hline Menor de 0,05 & 38 & 37 & 27 & 17 \\
\hline $\begin{array}{l}\text { Intermediate risk acute } \\
\text { lymphoblastic leukemia }\end{array}$ & $\mathrm{n}=42$ & $n=41$ & $\mathrm{n}=40$ & $n=36$ \\
\hline $\begin{array}{l}\text { Troponin } \mathrm{T} \\
>40 \\
\text { Troponin I } \\
>0.05\end{array}$ & $\begin{array}{l}42 \\
42\end{array}$ & $\begin{array}{l}41 \\
41\end{array}$ & $\begin{array}{l}40 \\
40\end{array}$ & $\begin{array}{c}351 \text { value of } 200 \\
36\end{array}$ \\
\hline $\begin{array}{l}\text { Standard risk acute lympho- } \\
\text { blastic leukemia }\end{array}$ & $\mathrm{n}=14$ & $n=14$ & $n=13$ & $n=13$ \\
\hline $\begin{array}{l}\text { Troponin T } \\
>40 \\
\text { Troponin I }\end{array}$ & 14 & 14 & 13 & 13 \\
\hline $\begin{array}{l}>0.05 \\
\text { Acute myeloid leukemia }\end{array}$ & $\begin{array}{c}14 \\
\text { At diagnosis }\end{array}$ & $\begin{array}{c}14 \\
\text { At the end } 7 \times 3(1)\end{array}$ & $\begin{array}{c}13 \\
\text { At the end } 7 \times 3(2)\end{array}$ & $\begin{array}{c}13 \\
\text { At the end of treatment }\end{array}$ \\
\hline $\begin{array}{l}\text { Troponin } \mathrm{T} \\
>40\end{array}$ & 18 & 18 & $\begin{array}{c}17 \\
1 \text { paciente } 116\end{array}$ & 17 \\
\hline $\begin{array}{l}\text { Troponin I } \\
>0.05\end{array}$ & 18 & 18 & 17 & 17 \\
\hline
\end{tabular}

